\title{
A discussão está aberta!
}

\author{
Discussion is open!
}

Francisco Eduardo de Campos

Soraya de Almeida Belisário

Ao encerrarmos este debate, temos a sensação de que valeu o esforço para colocar o tema em discussão. Como frisamos inicialmente, é um tremendo desafio trazê-la entre aqueles que somos: a um só tempo, participantes do esforço da construção do SUS e formadores dos novos profissionais de saúde. Seria por demais pretensioso tentar esgotar ou mesmo abordar todos os aspectos e possibilidades inerentes a um tema tão amplo, com tantas possibilidades e desdobramentos, em um artigo sucinto e delimitado. Contudo, aceitamos o desafio, mesmo correndo o risco de sermos incompletos. Procuramos pontuar aqueles que nos pareceram ser pontos cruciais para o despertar dessa discussão e acreditamos que a estratégia foi correta, uma vez que a relevância e a magnitude dos comentários nos demonstram a necessidade da continuidade e do aprofundamento da discussão.

A maioria daqueles que debateram nosso texto fizeram explicitamente o reconhecimento de que deve ser pautada uma discussão mais profunda sobre a modelagem do SUS e também de como enfrentar um de seus nós críticos: a adequação e adesão dos profissionais às propostas. Gostaríamos, portanto, de agradecê-los pelo respeito e seriedade com que participaram. O que está em pauta, de fato, é como se pode avançar para um sistema de saúde que mantenha os princípios basilares do SUS e, ao mesmo tempo, tenha qualidade e relevância social. Estamos todos de acordo: dificilmente isso se fará sem um sistema que trilhe a lógica da continuidade no cuidado e da responsabilização social, que recupere o elo entre equipes profissionais e usuários. As propostas vigentes até o surgimento da estratégia da Saúde da Família (SF) avançaram, mas foi um avanço insuficiente. Um claro exemplo é a criação do conceito do acolhimento, que se transformou em seita para muitos. Em muitas situações o "acolhimento" não passou de uma "glamourização" do velho conceito de triagem, provavelmente mais humanizada mas, ainda assim, irresolutiva. Ao contrário do que acontece em partidas de futebol, onde a divergência é permitida, o dogmatismo não abre espaço para discordância, disputa ou crítica.

Caso não haja ficado claro no texto que, mais que "o" modelo, o PSF é uma arena de debate político, onde velhos e novos atores sociais interagem, nossa proposta não foi entendida. Até mesmo porque esses atores sociais, muitos deles ativos participantes da construção do SUS, elevam o patamar dessa arena. Não é casual o fato de o Brasil provavelmente ser o único país latino-americano onde as propostas de focalização e cesta básica, formuladas pelos organismos internacionais, não tenham marcado a reforma do setor saúde. E os sanitaristas (sem aspas) brasileiros tiveram, sim, e continuarão a ter muita importância no avanço da consciência sanitária deste país. 
No que diz respeito ao avanço do ensino das profissões da saúde, o quadro brasileiro é também muito singular. Merhy assinala que nosso texto não dá o devido peso às propostas da CINAEM e ao desenvolvimento dos projetos UNI. Reconhecemos a CINAEM como uma iniciativa de enorme transcendência para o desenvolvimento da Educação Médica, mas o escopo do artigo transcende o tema. Na realidade, processos de mudança e inovação educativa não se desenvolvem num continuísmo evolucionista, mas a partir da acumulação e da reflexão sobre vitórias e derrotas passadas. Não poderíamos fazer uma análise do que passou nesta área sem citar, partindo do final dos anos sessenta, as experiências da inovação da Universidade de Brasília, do currículo experimental da FMUSP, da reforma da FM-UFMG, dos projetos de Integração Docente-Assistencial que se associaram em rede já em meados da década de oitenta, e, finalmente, dos projetos UNI, que representam, pela idéia da parceria entre academia, serviços e comunidade, reais possibilidades de avanço. Muito se publicou sobre este tema, o que certamente nos desobriga de repetir o óbvio.

O limitado espaço, mais uma vez, nos impossibilita de responder a cada debatedor em particular, já que por si só, cada uma das questões levantadas mereceria um texto também particular. Atenção especial deve ser dada à temática do trabalho de equipe, um desafio na construção do Projeto de Saúde da Família, como nos apontam Puntel e Mishima, a quem agradecemos. Muito recentemente aflorou uma publicação da OPAS/OMS e do Ministério da Saúde ${ }^{1}$ que trata exatamente desse tópico. Uma interessante metáfora é feita pela enfermeira Isabel Santos (comunicação pessoal), uma das autoras desse trabalho, sobre a diferença entre $o$ instrumentista solo e o trabalho da orquestra. Nem sempre o mais virtuoso solista tem a capacidade de interação e coordenação para fazer sua performance numa orquestra. De alguma forma, isso vem sucedendo no trabalho das equipes de Saúde da Família: ainda que cada profissional domine sua prática específica, há algo mais que a tradição secular do isolamento e a territorialidade das práticas não incutiu na formação profissional. Essa questão será um dos determinantes dos caminhos que trilhará a estratégia da Saúde da Família ou outra proposta que a suceda enquanto construção política no futuro.

Particular também é a discussão levantada por Alexandre Nemes acerca da necessidade de se aprofundar o debate sobre estratégias para alcançar as transformações necessárias no núcleo das práticas educacionais, tanto na graduação como na pósgraduação. Estamos de acordo e temos conclamado os gestores do SUS a exercerem papel protagônico de expressar suas necessidades às instituições acadêmicas, para que essas tenham retro-alimentação e redirecionem seus processos.

A referência, de forma genérica, aos Distritos Sanitários não invalida as intressantes e importantes experiências desenvolvidas no país dentro desta perspectiva, como nos aponta Paim. A afirmação contida no texto original acerca da debilidade da proposta dos Distritos Sanitários certamente não contempla a diversidade das situações existentes na América Latina (onde se aplicava correntemente o conceito do SILOS) e a particularidade da situação brasileira. Evidentemente existiram especificidades, situações particulares, nas quais houve teste de modelos tecnológicos de organização de serviços e, também, em que o compartilhamento de poder e a participação social deram contribuição decisiva à aproximação de um modelo com a preocupação de aperfeiçoar os propósitos basilares que inspiraram o SUS no caso brasileiro.

Ficamos felizes em termos tido esta oportunidade de intercambiar idéias e reflexões. Acreditamos que estamos todos contribuindo para o caminhar de um processo importante: o prosseguimento na construção democrática do SUS.

158 Interface - Comunic, Saúde, Educ 9
${ }^{1}$ Organização do Cuidado a partir de Problemas: Uma Alternativa Metodológica para Atuação da Equipe de Saúde da Família / José Paranaguá de Santana (org.); colaboração do Ministério da Saúde e do Pólo de Capacitação em Saúde da Família da UFMG: NESCON-

Faculdade de Medicina e Escola de Enfermagem. Brasília: Organização Pan-Americana da Saúde/Representação do Brasil, 2000.

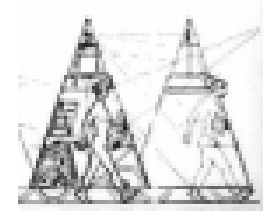

